\title{
Research on View of Vocational Selection and Employment Characteristics of Postgraduates Majored in Library Science and Information Science based on the data of South China Normal University
}

\author{
Li Huiqing, Wang Ying*
}

School of Economics and Management, South China Normal University, Guangzhou, Guangdong, China, 510006

*corresponding author, wangying@163.com

Keyword: the view of vocational selection; postgraduate students; employment characteristics; South China Normal University

\begin{abstract}
With the expansion enrollment of post-graduate, the situation of post-graduate employment is getting worse. This paper made the survey on the graduate students in South China Normal University from the year 2008 to 2014, and we found that the characteristics of postgraduate students majored in library science and information science are seeking for stability and security, focusing on the conversion of occupation in developed areas and low rate of changing jobs. We can make a meaningful job for post-graduate employment and gives some advice on how to improve the rate of post-graduate employment.
\end{abstract}

\section{Proposal of the Issue}

China's graduate education has expanded the scale since 2003. The number of enrollment of graduate students in 2014 is 551 thousands, 2.82 times than that of 2002 . Under the social background of China's industrial structure transformation and adjustment, streamline government institutions and state-owned enterprise reform, the society of graduates provide jobs and without a corresponding increase; at the same time, the employment policy from the allocation of the entrance examination to the "two-way choice", "self-employment" change. Based on the concern of the graduate employment problem, this paper uses the practical data. Analysis library and information professional graduate students view of employment and employment characteristics in order to improve and employment guidance in colleges and universities.

\section{Related Concepts and Research Background}

Vocational selection means choosing a career based on his professional ideals through a certain way. The view of vocational selection belongs to the content of ideological consciousness, which is the product of certain historical conditions, and closely related to social development. In order to facilitate the comparison and highlight the representative of graduate students' employment status, this paper chooses the books and the information professional graduates as the object of investigation. This paper takes the form of questionnaire survey to compare and analyze the employment situation of the seven graduate students in the school of economics and management of South China Normal University. The survey was distributed 103 questionnaires, 87 valid questionnaires were returned, reaching $84.47 \%$ of the total. In addition, we have carried out individual interviews to some of the graduates, the employment situation of the previous graduates were summarized and analyzed. Based on the data obtained from the questionnaire survey and individual interview in the library and information science major of South China Normal University, we made the following analysis of the graduates' vocational selection and employment situation. 


\section{Survey and Analysis}

\section{Purpose of Enrollment in Institutions}

Taking into account the impact of the employment concept, we have carried out a review of the research on the purpose of the students' enrollment in the design of the questionnaire. Through the investigation we found that out of sheer love of scientific research purposes and choose to pursue a degree in the proportion of students nearly seven years to basically every year for all graduate proportion $10 \%$ or so, most of the students are to improve education to better employment "for the purpose. This is close to the statistics of the proportion of graduates to continue to study, that is to say, the vast majority of students pursuing a degree in the purpose of achieving employment. This one is because of the increase in the pressure of employment.On the other hand, it is also the further requirement of the social progress of the individual's comprehensive quality.

\section{Regions of Employment}

Through the summary of recent years of employment, we can see that the employment of books, intelligence graduate students in the past seven years has changed little, mainly concentrated in the economically developed provinces. Never nearly seven years in graduate students select the economically less developed areas as the working location. This is mainly because, as the high degree of specialized personnel, the main setup of the employment unit exists in the developed and developing regions, especially in underdeveloped areas of library professionals are less in demand. Nearly seven years graduated from the graduate students and $85.62 \%$ of students from in economic development in provinces, accounting for the vast majority of the total number of the graduate students; from developed and less developed areas of the proportion of students were $10.66 \%$ and $3.72 \%$, indicating that graduate students in employment selection, with its own source of contact is not very close. Most of the graduate students will choose to work in the economically developed regions.

\section{Types of Employer}

Through the data of graduated students, we found that the graduation graduate choice of employment units showed the following characteristics: one is into colleges and universities and the research units the proportion of graduate students is decreasing year by year. Two is to enter the state organs and institutions to work the proportion of graduate students are essentially flat. Three is the proportion of each type of business to receive graduates has increased, which is the largest increase in state-owned enterprises. Finally, it is about continuing education. In nearly seven years of graduate students, the proportion of graduates who choose to continue to pursue doctoral degree is not high, and some fluctuations. This confirms our questionnaire about graduate school to the survey results, the vast majority of students' choice studying for a degree is to improve education in order to better employment.

\section{Ratio of Job Changing}

The nearly seven years of graduate students' employment tracking statistics can reflect a fact that after graduation of the conversion rate of job change ratio is not high, basically in $4 \%$ of wandering, indicating that graduate students in graduate job search process, the choice of employment unit is deliberate, stability. Once you have identified the work unit, the proportion of the conversion is not large. This further study validates the idea that we can find out is the stability and security of the graduates' employment.

\section{Influencing Factors Analyzation of Employment of Postgraduate Students}

In order to further analyze the factors that affect the employment of graduate students, we have summarized and analyzed the comprehensive situation of 103 books and information of the graduate students in the last seven years. In this paper, we use Logistic regression model to carry out empirical analysis. The above factors are included in the regression equation as independent variables, and the results are as follows: 
Table 1.Influencing Factors of Logistic Regression Model

\begin{tabular}{|c|c|c|c|c|c|c|}
\hline & $\mathrm{B}$ & S.E. & Wald & df & Sig. & Exp(B) \\
\hline Gender & 1.513 & 0.317 & 21.229 & 1 & 0 & 7.006 \\
\hline $\begin{array}{c}\text { University } \\
\text { before } \\
\text { Postgraduates }\end{array}$ & 1.412 & 0.213 & 4.406 & 1 & 0.007 & 5.17 \\
\hline Political Status & -0.306 & 0.314 & 2.701 & 1 & 0.091 & 0.593 \\
\hline English Level & 3.021 & 0.801 & 6.117 & 1 & 0.007 & 6.813 \\
\hline $\begin{array}{c}\text { Qualification } \\
\text { Certificate }\end{array}$ & 1.114 & 0.419 & 6.28 & 1 & 0.081 & 2.158 \\
\hline \begin{tabular}{c} 
Thesis Number \\
\hline $\begin{array}{c}\text { Work } \\
\text { Experience }\end{array}$
\end{tabular} & -0.597 & 0.139 & 4.21 & 1 & 0.021 & 0.699 \\
\hline Student Leader & 0.819 & 0.233 & 2.948 & 1 & 0.07 & 1.977 \\
\hline Constant & 0.061 & 0.817 & 0.009 & 1 & 0.831 & 2.064 \\
\hline
\end{tabular}

The overall regression model through the test of significance, SIG. Value $=0.000$ ). From the results we can be seen at the significance level of 0.005 , variables in the model in addition to the "political appearance" and "student cadre work and community activities situation", "professional qualification certificate" the three variables to, other variables on employment the final results have significant influence. Among the many factors, the influence of English on the employment is the most. Through statistical analysis, we can see, male graduate students obtain the possibility of working in the same condition is more than seven times the female graduate students, and Library and Information Studies students employment direction of the traditional focus in Library of colleges and universities, scientific research units as well as the public library. Other aspects of the factors, the possibility of obtaining a job through the university English six test is not through the 6.8 times. This shows the importance of English ability to job search. Graduates studying for a degree at your school grade are second only to the English ability of the second impact factors. Before going to graduate school graduation in 211 institutions of graduate students in the same conditions, the possibility of obtaining a work is 5.1 times non-211 graduates of the college. In general, with good English skills and a solid professional knowledge base, it is helpful to improve the employability of graduates and increase their chances of finding a good job.

\section{Conclusions and Suggestions}

\section{Improve Employment Education}

The objectives to go to graduate school for further study are employments for a degree through the vast majority data. Graduate training institutions should focus on improving the students' practical ability, innovation ability and development ability, improve the comprehensive quality of graduate will throughout the whole process in postgraduate training; in postgraduate training curriculum setting should embody creativity, applied and comprehensive, cultivate the compound talents of all-round development. Student management department can meet the requirements of the comprehensive development of the graduate students through social practice, campus cultural activities and so on.

\section{Broaden Employment Regions}

From nearly seven years of graduate student employment situation, the vast majority of graduate students are choosing economically developed areas as employment areas; but in the economic construction of our country, the central and western regions, and remote areas of high level talent demand. Graduate management departments should be by strengthening the work of Ideological 
and political education, guide the students to establish correct world outlook, outlook on life and values; to guide the students to look at the problem with the vision of development, look to the future, and society, the construction of the motherland, to economically less developed regions.

\section{Strengthen Employment Guidance}

The conversion rate of graduate students is low. Graduate students have some stability in the development of career. Therefore, Graduate Management by enhancing graduate employment guidance efforts, through the development of career education, help the students of professional and social needs, students to provide scientific guidance, and make them have a clear understanding of the employment situation, career teaching education runs through the whole process in postgraduate training.

\section{Support Disadvantage Group of Employment}

The empirical results show that the female students, the poor rank students and the low level of undergraduate university students have some disadvantages in hunting a good job. For the disadvantaged groups, the government and the university should give the support and guidance to enhance the competitiveness of employment.

\section{References}

[1] Wang Ying, Empirical Study on Economics Postgraduate StudentsVocational Selection and Employment Characteristics, J. Journal of Guangdong Polytechnic Normal University. 2014(1):116-121.

[2] Song Xiaomei, Research on the Employment Characteristics and the Employment Policies of Ordos City in Inner Mongolia-As a Resource-based City in the Process of Economic Transition in China, C.Proceedings of 2011 International Conference on Public Administration(7th).2011

[3] Chu Xiang, Research on New Concepts of Vocational Guidance of Undergraduates, J, Overseas English. 2013(12):86-88. 